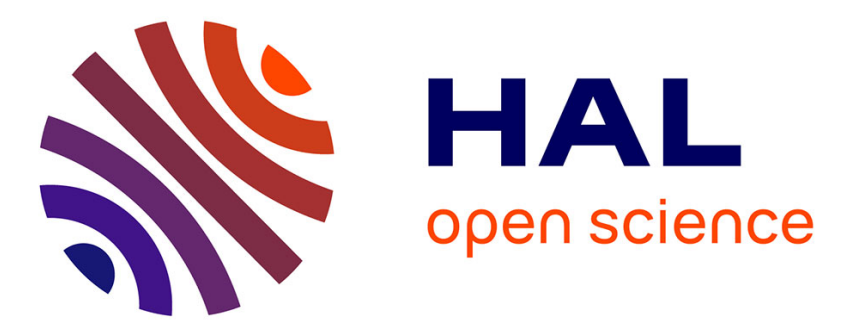

\title{
Association of 1-deoxy-sphingolipids with steatosis but not steatohepatitis nor fibrosis in non-alcoholic fatty liver disease
}

J. Weyler, A. Verrijken, T. Hornemann, L. Vonghia, E. Dirinck, A. von Eckardstein, T. Vanwolleghem, P. Michielsen, F. Peiffer, A. Driessen, et al.

\section{To cite this version:}

J. Weyler, A. Verrijken, T. Hornemann, L. Vonghia, E. Dirinck, et al.. Association of 1-deoxysphingolipids with steatosis but not steatohepatitis nor fibrosis in non-alcoholic fatty liver disease. Acta Diabetologica, 2020, 58 (3), pp.319-327. 10.1007/s00592-020-01612-7 . inserm-03180573

\section{HAL Id: inserm-03180573 https://www.hal.inserm.fr/inserm-03180573}

Submitted on 25 Mar 2021

HAL is a multi-disciplinary open access archive for the deposit and dissemination of scientific research documents, whether they are published or not. The documents may come from teaching and research institutions in France or abroad, or from public or private research centers.
L'archive ouverte pluridisciplinaire HAL, est destinée au dépôt et à la diffusion de documents scientifiques de niveau recherche, publiés ou non, émanant des établissements d'enseignement et de recherche français ou étrangers, des laboratoires publics ou privés. 


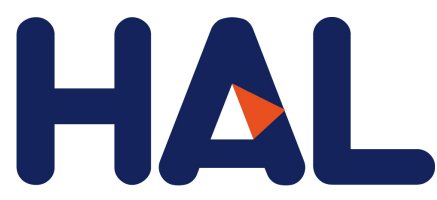

archives-ouvertes

\title{
Association of 1-deoxy-sphingolipids with steatosis but not steatohepatitis nor fibrosis in non-alcoholic fatty liver disease
}

\author{
J. Weyler, A. Verrijken, T. Hornemann, L. Vonghia, E. Dirinck, A. von \\ Eckardstein, T. Vanwolleghem, P. Michielsen, F. Peiffer, A. Driessen, et al.
}

\section{To cite this version:}

J. Weyler, A. Verrijken, T. Hornemann, L. Vonghia, E. Dirinck, et al.. Association of 1-deoxysphingolipids with steatosis but not steatohepatitis nor fibrosis in non-alcoholic fatty liver disease. Acta Diabetologica, Springer Verlag, 2021, 58 (3), pp.319-327. 10.1007/s00592-020-01612-7 . inserm03180573

\section{HAL Id: inserm-03180573 https://www.hal.inserm.fr/inserm-03180573}

Submitted on 25 Mar 2021

HAL is a multi-disciplinary open access archive for the deposit and dissemination of scientific research documents, whether they are published or not. The documents may come from teaching and research institutions in France or abroad, or from public or private research centers.
L'archive ouverte pluridisciplinaire HAL, est destinée au dépôt et à la diffusion de documents scientifiques de niveau recherche, publiés ou non, émanant des établissements d'enseignement et de recherche français ou étrangers, des laboratoires publics ou privés. 


\section{Title page}

2 Title: Association of 1-deoxy-sphingolipids with steatosis but not steatohepatitis nor fibrosis

3 in Non-Alcoholic Fatty Liver Disease

$4 \quad$ Key words: Non-Alcoholic Fatty Liver Disease, 1-deoxy-sphingolipids

5 Authors: J. Weyler* ${ }^{1,2}$, A. Verrijken* ${ }^{2,3}$, T. Hornemann* ${ }^{4,5}$, L. Vonghia ${ }^{1,2}$, E. Dirinck ${ }^{2,3}$, A. von

6 Eckardstein $^{4}$, T. Vanwolleghem ${ }^{1,2}$, P. Michielsen, ${ }^{1,2}$, F. Peiffer ${ }^{2,3}$, A. Driessen ${ }^{6}$, G. Hubens $^{6}$, B.

7 Staels $^{8}$, S. Francque ${ }^{\# 1,2}$, L. Van Gaal ${ }^{\# 2,3}$

$8 \quad *$ shared first authorship

$9 \quad$ \# shared senior authorship

\section{Affiliations:}

$11{ }^{1}$ Department of Gastroenterology and Hepatology, Antwerp University Hospital, Edegem,

12 Belgium

$13{ }^{2}$ Laboratory of Experimental Medicine and Paediatrics, University of Antwerp, Belgium

$14{ }^{3}$ Department of Endocrinology, Diabetology and Metabolic Diseases, Antwerp University

15 Hospital, Edegem, Belgium

$16{ }^{4}$ Institute for Clinical Chemistry, University Hospital Zurich and Center for Integrative

17 Human Physiology, University of Zurich, Switzerland

$18{ }^{5}$ Competence Center for Systems Physiology and Metabolic Diseases, University of Zurich,

19 Switzerland

${ }^{6}$ Department of Pathology, Antwerp University Hospital, Edegem, Belgium 
$21{ }^{7}$ Department of Abdominal Surgery, Antwerp University Hospital, Edegem, Belgium

$22{ }^{8}$ Univ. Lille, Inserm, CHU Lille, Institut Pasteur de Lille, U1011-EGID, F-59000 Lille,

23 France

24

25 Corresponding author: prof. dr. Sven Francque

26

Department of Gastro-enterology and Hepatology

27

Wilrijkstraat 10

28

2650 Edegem

29

Belgium

30

31

32 
33

Disclosures

34 This work is part of the European Commission projects HEPADIP (Hepatic and adipose tissue and functions in the metabolic syndrome; Contract LSHM-CT-2005-018734) and RESOLVE (A systems biology approach to RESOLVE the molecular pathology of two hallmarks of patients

37 with metabolic syndrome and its co-morbidities; hypertriglyceridemia and low HDLcholesterol; contract FP7-305707). BS is a recipient of an ERC Advanced Grant (694717). SF

39 holds a senior research fellowship from the Fund for Scientific Research (FWO) Flanders $40 \quad(1802154 N)$.

41

42 Number of Tables: 2 and 3 supplemental tables

43 Number of Figures: 2

44 Word count: 4257 
$47 \quad$ ALP

$48 \quad \mathrm{ALT}$

$49 \quad$ AST

$50 \mathrm{BMI}$

$51 \quad \mathrm{C}_{16}-\mathrm{SA}$

$52 \quad \mathrm{C}_{16}-\mathrm{SO}$

$53 \quad \mathrm{C}_{17}-\mathrm{SO}$

$54 \quad \mathrm{C}_{18}-\mathrm{SA}$

$55 \quad \mathrm{C}_{18}-\mathrm{SO}$

$\mathrm{C}_{18}$-phyto-SO

$\mathrm{C}_{18}$-phyto-sphingosine

$57 \quad \mathrm{C}_{19}-\mathrm{SO}$

$\mathrm{C}_{19}$-sphingosine

$58 \quad \mathrm{C}_{20}-\mathrm{SA}$

$\mathrm{C}_{20}$-sphinganine

$59 \quad \mathrm{C}_{20}-\mathrm{SO}$

$\mathrm{C}_{20}$-sphingosine

$60 \quad C D$

Confidence Distribution

61

$\mathrm{Cl}$

Confidence Interval

62 deoxy-SA

63 deoxy-SO

deoxy-sphingosine

64 DSB

1-Deoxy Sphingoid Base

$65 \mathrm{dSL}$

deoxy SphingoLipids

$66 \quad$ FLIP

Fatty Liver Inhibition of Progression

$67 \quad$ VGT

gamma Glutamyl Transpeptidase

$68 \quad \mathrm{HbA}_{1 \mathrm{c}}$

Haemoglobin $A_{1 c}$

69 HDL-C

High Density Lipoprotein-Cholesterol 
$71 \quad$ IFG

72 IGT

$73 \quad$ IR

74 LDL-C

75 MetS

$76 \quad$ NAFL

77 NAFLD

$78 \quad \mathrm{NASH}$

79

$80 \quad$ OGTT

81 PPAR

82 SA

83 SA-dienine

84 SO

85 S1P

86 SphK

$87 \quad$ SPT

$88 \quad$ TG

89 T2DM

90 WC

91

92
Homeostatic Model Assessment

Impaired Fasting Glucose

Impaired Glucose Tolerance

Insulin Resistance

Low Density Lipoprotein-Cholesterol

Metabolic Syndrome

Non-Alcoholic Fatty Liver

Non-Alcoholic Fatty Liver Disease

Non-Alcoholic Steatohepatitis

Non-Alcoholic Steatohepatitis with significant fibrosis

Oral Glucose Tolerance Test

Peroxisome Proliferator-Activated Receptor

Sphinganine

Sphingadienine

Sphingosine

Sphingosine-1-Phosphate

Sphingosine Kinase

Serine-Palmitoyl Transferase

TriGlycerides

Type 2 Diabetes Mellitus

Waist Circumference 
93

94

95

96

97

\section{Abstract}

Background: Non-Alcoholic Fatty Liver Disease (NAFLD) is the most important cause of chronic liver disease in the western world. In some individuals liver steatosis can be accompanied by inflammation and cell damage (Non-Alcoholic Steatohepatitis, NASH), and even liver fibrosis. Sphingolipids are a heterogeneous class of lipids and essential components of the plasma membrane and plasma lipoproteins. The atypical class of deoxysphingolipids have been implicated in the metabolic syndrome and type 2 diabetes.

Aim: To determine if circulating (deoxy)sphingolipids are associated with NAFLD and its different entities, steatosis, inflammatory changes (inflammation and ballooning) and fibrosis.

Methods: Sphingolipids were analysed by LC-MS after hydrolysing the $\mathrm{N}$-acyl and O-linked headgroups in plasma of obese adults who underwent a liver biopsy in suspicion of NAFLD.

Results: 288 patients were included, liver status was as follows: $17.7 \%$ control, $16.3 \%$ NAFL (Non-Alcoholic Fatty Liver or isolated steatosis), 51.7\% NASH without significant fibrosis and 14.3\% NASH with significant fibrosis. There was no association between typical sphingolipids and NAFLD and its different entities. There was a statistically significant association between the presence of steatosis and the concentrations of deoxy-sphinganine (exp(B) 11.163 with $\mathrm{Cl}[3.432,36.306]$ and $\mathrm{p}<0.001)$ and deoxy-sphingosine $(\exp (\mathrm{B}) 8.486$ with $\mathrm{Cl}[3.437,20.949]$ and $p<0.001)$. There was no association between these deoxy-sphingolipids and activity of the steatohepatitis, nor was there any association with fibrosis. Differences in deoxysphingolipids also correlated independently with the presence of the metabolic syndrome, but not diabetes. 
115 Conclusion: Deoxy-sphingolipids are elevated in patients with steatosis compared to those

116 without fatty liver, but not different between the different NAFLD subtypes, suggesting that

117 deoxy-sphingolipid bases might be involved in steatogenesis, but not in the further 118 progression of NAFLD to NASH nor in fibrogenesis. 
NAFLD

122

Non-Alcoholic Fatty Liver Disease (NAFLD) is the most important cause of chronic liver disease in the western world. In some individuals liver steatosis can be accompanied by liver cell damage, inflammation, and even liver fibrosis. The latter can lead to cirrhosis which can further result into end-stage liver disease[1]. The pathogenesis of NAFLD is still not completely elucidated. Presumably, the integrated action of numerous conditions acting in parallel (genetic predisposition, adipose tissue dysfunction, insulin resistance (IR), oxidative stress, lipotoxicity, gut dysbiosis...) results in NASH, giving rise to the multiparallel hit hypothesis[2]. Different studies have shown that fibrosis grade is the strongest predictor for hepatic- and extra-hepatic complications[3, 4], whereas steatohepatitis is considered the driving force of disease progression and adverse outcomes.

\section{Sphingolipids}

Sphingolipids are a heterogeneous class of bioactive lipids with a plethora of functions playing important roles in almost all major aspects of cell biology including metabolism, inflammation, autophagy and cell adhesion and migration[5]. Furthermore, they are major components of cell membranes and contribute to plasma lipoprotein formation. The enzyme Serine-Palmitoyl Transferase (SPT) catalyses the first and rate-limiting step in the de novo synthesis of sphingolipids, which converts L-serine and palmitoyl-CoA into 3-ketosphinganine. The latter is converted into sphinganine (SA). SA is N-conjugated with another fatty acid to form dihydro-ceramide. When desaturated at $\mathrm{C} 4$ it forms ceramide, the building block for the more complex sphingolipids (Fig. 1)[6]. Ceramidase converts ceramide into sphingosine (SO), the most abundant long-chain sphingoid base in mammalian cells. 
Sphingosine-1-Phosphate (S1P) is formed after phosphorylation of SO by two Sphingosine Kinases (SphK1 and -2)[7]. In plasma, SO is the most common sphingoid base, followed by sphingadienine (SA-dienine) and SA[8]. Ceramide and S1P have been implicated in key steps of the pathophysiology of NAFLD in animal models[7]. Data in humans are, however, scarce. L-serine and palmitoyl-CoA are the preferred substrates for SPT, however, other substrates can be used, including acyl-CoA with carbon chain lengths ranging from C12 to C18. Furthermore, SPT can use other amino acid substrates beside L-serine: L-alanine and to a certain extent L-glycine. The use of these alternative substrates generates a category of atypical sphingolipids: the 1-Deoxy Sphingolipids (dSLs) that lack the $\mathrm{C1}-\mathrm{OH}$ group of the regular sphingolipids (Fig. 1). dSLs are not metabolised to form complex sphingolipids nor are they degraded by the regular sphingoid catabolism pathway[9]. The function of these dSLs is unknown. dSL levels were shown to be increased in plasma of patients with the Metabolic Syndrome (MetS) and Type 2 Diabetes Mellitus (T2DM)[9]. Furthermore, they could play a role in the pathogenesis of T2DM with the dSLs being cytotoxic for insulin producing cells as they induce senescence and multiple cell death pathways[10]. NAFLD, MetS and T2DM are closely related and originate from the same underlying pathological processes, such as IR, lipotoxicity, dyslipidaemia and chronic inflammation[11]. Since there is a correlation between the MetS, T2DM and (deoxy)sphingolipids, on the one hand, and a close relationship between the MetS, T2DM and NAFLD, on the other hand, we aimed at investigating whether :

1. circulating (1-deoxy) sphingoid bases are associated with NAFLD and its different components, steatosis, cell damage \& inflammatory changes (lobular inflammation and ballooning) and fibrosis; 
2. associations between deoxy-sphingolopids, on the one hand, and the MetS or T2DM, on the other hand, are driven by the presence of NAFLD and its different components.

\section{Patients \& Methods}

\section{Study participants}

The protocol of patient selection has previously been described[12]. Briefly, patients visiting the obesity clinic of the Antwerp University Hospital were consecutively recruited. Every patient underwent a metabolic and hepatologic work-up both approved by the Ethics Committee of the Antwerp University Hospital (reference 6/25/125, Belgian registration number B30020071389) in order to screen for NAFLD. Subjects had to be 18 years or older. As T2DM harbours potential confounders, patients with a known history of diabetes were excluded. However, patients were included if diabetes was newly diagnosed. Sample collection for sphingolipid analysis was taken before any glucose lowering therapy was started. Patients with significant alcohol consumption were excluded. A liver biopsy was proposed if there was a suspicion of liver disease, these were mainly performed outside the setting of bariatric surgery in order to exclude severe liver abnormalities prior to surgery. Only patients who underwent a liver biopsy were included for this study. Biopsies deemed insufficient for adequate reading by the pathologist were excluded from further analysis. The different pathological features of NAFLD were scored according to both the NASH Clinical Research Network Scoring System and the Fatty Liver Inhibition of Progression (FLIP)-algorithms[13, 14]. The diagnosis of NASH required the combined presence of steatosis, ballooning and lobular inflammation. Based on liver histology, patients were classified in 4 distinct groups reflecting different stages of severity of the disease: 
- No-NAFLD: no histological evidence for steatosis, inflammation, ballooning and fibrosis

- Isolated steatosis (or NAFL): histological evidence of steatosis with activity score (ballooning+inflammation) $\leq 1$ and fibrosis stage $\leq 1$

- NASH without significant fibrosis (fibrosis stage $(F)<2$ ): histological evidence of steatosis with ballooning score $\geq 1$, inflammation score $\geq 1$ and fibrosis stage $\leq 1$

- NASH with significant fibrosis ( $\geq F 2$ ) (so called "fibrotic NASH"): histological evidence of steatosis with ballooning score $\geq 1$, inflammation score $\geq 1$ and fibrosis stage $\geq 2$.

Patients with histological evidence of a liver disease other than NAFLD or patients with NAFLD but who could not be unequivocally categorised in one of the 4 groups were excluded.

\section{Sphingolipid analysis}

The protocol for analysing plasma sphingoid bases has previously been described[15]. Briefly, sphingoid bases were determined in fasting plasma samples. Sphingolipids in plasma are present in a broad variation of subspecies. They can be saturated and are usually acylated with another fatty acid. Furthermore, most of these sphingolipids are conjugated to an O-linked head group. To analyse the sphingoid backbones, the sphingolipids were subjected to a sequential acid and base hydrolysis. Acid hydrolysis specifically breaks the Nalkyl chain, whereas alkaline conditions lead to a release of the O-linked head group. The sphingoid bases were analysed using Liquid Chromatography/Mass Spectrometry. Analysed bases included $\mathrm{C}_{16}$-sphinganine $\left(\mathrm{C}_{16}\right.$-SA), $\mathrm{C}_{16}$-sphingosine $\left(\mathrm{C}_{16}\right.$-SO), $\mathrm{C}_{17}$-sphingosine $\left(\mathrm{C}_{17}\right.$-SO), $\mathrm{C}_{18}$-sphinganine $\left(\mathrm{C}_{18}\right.$-SA), $\mathrm{C}_{18}$-sphingosine $\left(\mathrm{C}_{18}\right.$-SO), $\mathrm{C}_{19}$-sphingosine $\left(\mathrm{C}_{19}\right.$-SO), $\mathrm{C}_{20}$-sphinganine 
$211\left(\mathrm{C}_{20^{-}} \mathrm{SA}\right), \mathrm{C}_{20^{-}}$-sphingosine $\left(\mathrm{C}_{20^{-}} \mathrm{SO}\right)$, sphingadienine (SA-dienine), $\mathrm{C}_{18^{-}}$-phyto-sphingosine $\left(\mathrm{C}_{18^{-}}\right.$ 212 phyto-SO), deoxy-sphinganine (deoxy-SA) and deoxy-sphingosine (deoxy-SO).

213 


\section{The role of sphingolipids in the different entities of NAFLD}

Data were analysed with SPSS version 24 . Means were compared by independent t testing or non-parametric tests when appropriate. To investigate the association of sphingoid bases with the different entities of NAFLD (steatosis, steatohepatitis and fibrosis), the following groups were compared: 'No-NAFLD' vs. 'NAFL' to investigate the association of the sphinghoid bases in steatosis; 'NAFL' vs. 'NASH $<F 2$ ' to investigate the potential association of the sphingoid bases in steatohepatitis and eventually 'NASH $<F 2$ ' $v s$. 'NASH $\geq F 2$ ' to investigate the potential association of the sphingoid bases in fibrogenesis. Sphingoid bases that showed association with NAFLD (and its stages) in this first crude analysis were further analysed using binary logistic regression. Since NAFLD is closely related to the MetS and diabetes mellitus type 2, interaction with or confounding is possible. Furthermore, certain lipid lowering therapies can have a profound effects on NAFLD. Adjustment was done using metabolic markers (e.g. homeostasis model assessment (HOMA)-IR, presence of the MetS, presence of T2DM or Impaired Fasting Glucose (IFG) and the use of lipid lowering therapy) as covariates and/or interaction terms in a binary logistic regression.

\section{Deoxy-sphingoid bases and metabolic parameters}

To investigate whether the associations between deoxy-sphingolopids, on the one hand, and the MetS or T2DM, on the other hand, are driven by NAFLD, the possible confounding/interaction effect of NAFLD was checked using binary logistic regression analysis. Furthermore, correlations between deoxy-sphingolipids and other metabolic parameters (e.g. triglycerides and HOMA-IR) were checked. To investigate these correlations, Pearson's correlation coefficient was used when appropriate. If not, non- 
237 parametric testing was performed: Kendall's tau-b was used if there were a great number of 238 tied ranks, in others cases Spearman's rho was used.

239

240 


\section{RESULTS}

\section{The role of sphingolipids in the different entities of NAFLD}

288 consecutive patients with a complete dataset were included. Their liver phenotype was as follows: $17.7 \%$ No-NAFLD, $16.3 \%$ NAFL, $51.7 \%$ NASH $<$ F2 and $14.3 \%$ NASH $\geq F 2$. This is an obese study population with a mean BMI of $39.6 \mathrm{~kg} / \mathrm{m}^{2}$ (SD 6.4) (Table 1). Log transformation of the concentration of sphingoid bases was used in statistical analysis since the distribution of these bases was skewed (resulting in extreme exp (B) values).

There were 47 patients with isolated liver steatosis and 51 (26.6\%) patients with no histological evidence for the presence of NAFLD (No-NAFLD). There was a statistically significant difference in age, waist and $\mathrm{HbA}_{1 c}$, but there was no difference in $\mathrm{BMI}$, presence of the Mets and presence of T2DM. There was no use of fibrates and statin use was not significantly different in both groups (Supplementary Table 1). There was a statistically significant association between the presence of steatosis and the concentrations of deoxySA (exp(B) 6.708 with $\mathrm{Cl}[1.243,36.195]$ and $\mathrm{p} 0.027)$ and deoxy-SO (exp(B) 4.851 with $\mathrm{Cl}$ $[1.315,17.890]$ and 0.018$)$. There was no interaction effect of metabolic markers in the association of steatosis and the sphingoid bases deoxy-SA and deoxy-SO, and statistical significance was maintained for the DSBs (deoxy-SA and deoxy-SO) even after correction for confounding (e.g. by metabolic markers). 
149 patients had NASH, compared to 47 patient with isolated steatosis. There was a statistically significant difference in the presence of the MetS, HOMA-IR and liver enzymes (Supplementary Table 2). There was a statistically significant difference in plasma concentrations of $\mathrm{C}_{16}-\mathrm{SO}, \mathrm{C}_{17}-\mathrm{SO}, \mathrm{C}_{18}-\mathrm{SO}$ and $\mathrm{SA}$-dienine. Further analysis did, however, not show an association between $\mathrm{NASH}$ and $\mathrm{C}_{16}$-SO $(\exp (\mathrm{B}) 0.159$ with $\mathrm{Cl}[0.016,1.595]$ and $\mathrm{p}=0.118)$ nor $\mathrm{C}_{17}-\mathrm{SO}(\exp (\mathrm{B}) 0.106$ with $\mathrm{Cl}[0.008,1.342]$ and $\mathrm{p}=0.083)$. There was a statistically significant association between $\mathrm{NASH}$ and $\mathrm{C}_{18}-\mathrm{SO}(\exp (\mathrm{B}) 0.036$ with $\mathrm{Cl}[0.001$, $0.991]$ and $p$ 0.049) and SA-dienine $(\exp (B) 0.037$ with $[0.002,0.725]$ and $p$ 0.030). There was no interaction effect by the metabolic markers. However, after correction for the presence of the MetS there was a loss of the statistically significant association between $\mathrm{NASH}$, on the one hand, and $\mathrm{C}_{18}-\mathrm{SO}(\exp (\mathrm{B}) 0.043$ with $\mathrm{Cl}[0.001,1.405]$ and $\mathrm{p} 0.077)$ and SAdienine $(\exp (\mathrm{B}) 0.062$ with $\mathrm{Cl}[0.003,1.414]$ and $\mathrm{p} 0.081)$, on the other hand.

\section{1c. Sphingoid bases in NASH $<F 2$ vs. NASH $\geq F 2$}

41 patients with NASH had evidence of significant fibrosis (fibrotic NASH), compared to 149 (26.6\%) NASH patients who had no significant fibrosis (Supplementary Table 3). There was a statistically significant association between fibrotic $\mathrm{NASH}$ and the concentrations of $\mathrm{C}_{19}$-SO $(\exp (B) 0.157$ with $\mathrm{Cl}[0.025,0.986]$ and $\mathrm{p}=0.048)$ and SA-dienine $(\exp (\mathrm{B}) 0.013$ with $\mathrm{Cl}$ $[0.001,0.342]$ and $p=0.009)$. There was no interaction between metabolic markers and the sphingoid bases $\mathrm{C}_{19}$-SO and SA-dienine. After correcting for HOMA-IR, however, there was loss of statistical significance for the association between fibrotic NASH and $\mathrm{C}_{19}$-SO (exp(B) after correction 0.203 with $\mathrm{Cl}[0.028,1.495]$ and $p=0.118)$. Furthermore, there was a loss of 
statistical significance for the association between fibrotic NASH and SA-dienine after correcting for gender $(\exp (\mathrm{B})$ after correction 0.048 with $\mathrm{Cl}[0.001,1.213]$ and $\mathrm{p}=0.065)$.

\section{Deoxy-sphingoid bases and metabolic - parameters}

Log transformation of the concentration of sphingoid bases was used in binary regression analysis since the distribution of these bases was skewed (resulting in extreme exp (B) values).

\section{2a. Metabolic syndrome}

There was a highly statistically significant association between MetS and the concentrations of deoxy-SA (exp(B) 29.934 with $\mathrm{Cl}[8.457,105.949]$ and $\mathrm{p}<0.001)$ and deoxy-S0 (exp(B) 29.024 , with $\mathrm{Cl}[9.796,85.998]$ and $\mathrm{p}<0.001)$. There was no interaction with the metabolic markers (including T2DM) nor with NAFLD, nor was there loss of statistical significance after correction for the metabolic markers (including T2DM and HOMA-IR) nor NAFLD

\section{2b. Type 2 diabetes mellitus}

There was a highly statistically significant association between the presence of T2DM and the concentrations of deoxy-SA (exp(B) 14405.280 with $\mathrm{Cl}[13.084,15860091.190]$ and $\mathrm{p}$ 0.007) and deoxy-S0 (exp(B) 7.953 with $\mathrm{Cl}[1.832,34.515]$ and $\mathrm{p} 0.006)$. There was no interaction with metabolic markers (including MetS) nor with NAFLD. After correction for the MetS, however, there was a loss of a statistically significant association between T2DM and deoxy-SA (exp(B) after correction 1.964 with $\mathrm{Cl}[0.275,14.048]$ and $p=0.501)$ and deoxySO $(\exp (\mathrm{B})$ after correction 2.138 with $\mathrm{Cl}[0.400,11.432]$ and $\mathrm{p}=0.374)$. 
307 There was a statistically significant correlation between the DSBs and triglycerides (Fig 2A 308 and 2B; Spearman's rho 0.553 and $p<0.001$ for deoxy-SA and Spearman's rho 0.581 and $p$ $309<0.001$ for deoxy-SO) and between deoxy-SA and IR. There was no statistically significant 310 correlation between deoxy-SO and IR (Fig 2C and 2D; Spearman's rho 0.1138 and p 0.021 for 311 deoxy-SA and Spearman's rho 0.104 and $\mathrm{p} 0.081$ for deoxy-SO) (Table 2). 
313

314

315

316

317

\section{Discussion}

Sphingolipids are essential components of the cell membrane and plasma lipoproteins. They play a complex role as signalling molecules in multiple processes and have been suggested to be of pathophysiological relevance in NASH. dSLs, an atypical category of sphingolipids, are generated when SPT uses L-alanine instead of L-serine. dSLs are neither metabolised to complex sphingolipids nor degraded by the sphingolipid catabolism pathways. There function is not clear, but they seem involved in T2DM and the MetS.

In a large, well characterised, prospectively screened cohort with ultimately histological diagnosis of NAFLD we observed a highly significant association between NAFLD and 1deoxy sphingoid bases (DSBs). We found no statistically significant difference between the different stages of NAFLD, suggesting that dSLs are related to steatosis, but are not implicated in the further progression of NAFLD to NASH and not associated with fibrosis. Furthermore, this study confirms the association of deoxy-sphingolipids with the MetS but not diabetes.

In a study with 99 individuals, Bertea et al. found a statistical significant difference in plasma dSLs levels when comparing T2DM patients with control. Although there was a clear difference between these groups regarding gender, BMI and other metabolic markers, there was no correction performed, questioning these findings. Furthermore, they described a possible predictive role of dSLs for the presence of T2DM, although this case-control study did not lean itself to perform prediction analysis [9]. Also Othman et al investigated the role of dSLs in the MetS and T2DM. They found a significant difference between plasma levels of dSLs when comparing healthy volunteers with patients with the MetS or patients with T2DM, but found no difference between plasma levels of dSLs when comparing T2DM with 
MetS. In this study, there was a statistically significant difference in BMI and waist circumference when comparing patients with T2DM to those with the Mets, and a (near statistically) significant difference when comparing triglycerides, but there was no correction performed [16].

Human data regarding the association between sphingolipids, more specifically, dSLs on the one hand, and the presence of NAFLD, on the other, is scarce. Gorden et al described a diverse panel of 20 plasma lipids, including the dSL 1-deoxy-ceramide, capable of distinguishing NAFLD from NASH in 88 patients with liver histology categorised as normal, steatotic, NASH, or cirrhotic. Although patients were selected on an "all-comers" approach where liver biopsy was obtained during surgery (gastric bypass, liver transplant, multi organ transplant, hernia repair...), the study population was obese with a mean fasting glucose > $100 \mathrm{mg} / \mathrm{dL}$ (other metabolic conditions were not mentioned). The possible effects of these conditions on the results was not assessed, meaning that an overestimation of the discriminate power of these lipids is possible [17]. Gai et al. reported a correlation between NAFLD and dSLs in 80 individuals, but failed to specify the contribution of these dSLs in the different entities of NAFLD. Furthermore, they did not provide a clear overview of the main (metabolic) characteristics of these patients and failed to check for the confounding or interactive effect of metabolic factors [18]. The role of dSLs in the MetS, T2DM and NAFLD is not fully understood, but they seem to play a role in the control of metabolism. A study by Zuellig et al. showed that dSLs compromised insulin secretion and triggered senescence and cell-death in insulin producing cells triggered by multiple pathways, including cytoskeletal remodelling, senescence, necrosis and apoptosis favouring hyperglycaemia. [10] Although we found an increasing presence of de novo T2DM with a more severe phenotype of NAFLD, there was no significant interaction between de novo T2DM nor IR and dSLs when 
investigating the association with steatosis, nor was there loss of significance after correcting for T2DM or IR (data for T2DM not shown) suggesting that hyperglycaemia or IR per se is not a determinant of dSL formation in the pathophysiology of NAFLD. On the other hand, dSLs do not significantly differ between the 3 NAFLD categories whereas IR and impairment of glycaemic control worsen as disease worsens (despite comparable age and BMI). This observation hence does not support an important role for dSLs in impairment of glucose metabolism in NAFLD. Wei et al. also speculated that the formation of dSLs in T2DM is not caused by hyperglycaemia per se, but rather associated with metabolic changes in T2DM [19].

Another possible explanation in the association between dSLs and NAFLD is a shift in the utilization of alanine instead of serine by SPT. Mardinoglu et al. revealed a L-serine deficiency in NAFLD using a genome scale metabolic model of hepatocytes. As seen in literature, there was a significant association between T2DM and DBSs[9] and between the MetS and dSLs[16], which was also the case in our population. However, after correcting for the MetS, there is a loss of statistical significance in the association between dSLs and T2DM. Furthermore, this association between dSLs and MetS is not driven by the presence of NAFLD (since the lack of a significant interaction). Although it is not clear what exact role the DSBs play in steatosis, they seem to be associated with metabolic dysregulation, which might eventually lead to steatosis.

Sphingolipid metabolism has been proposed as a target for pharmacological therapy of NASH. Othman et al showed that fibrates have a DSBs lowering effect, independent of a triglyceride lowering effect [19]. It is not clear whether this is a peroxisome proliferatoractivated receptor (PPAR) $\alpha$ or non-PPAR $\alpha$ mediated effect[20]. Gai et al. described that the 
activation of Farnesoid X Receptor reduces dSLs plasma levels in a high fat-fed mouse model and in 1-deoxysphinanine-treated mice [18]. Another group found that oral supplementation of serine suppressed the formation of dSLs in an hereditary sensory and autonomic neuropathy type 1 (HSAN1) animal model and in humans[21, 22]. Serine palmitoyltransferase long chain base subunit 1 and 2 mutations in SPT (as seen in HSAN1) induce a permanent shift in the substrate preference from L-serine to L-alanine[6]; dSLS formation in metabolic diseases is, however, not caused by a mutation in SPT but by a dysregulation in carbohydrate and fatty acid metabolism [19]. Our data are linking dSLS more to steatosis than to steatohepatitis and fibrosis (at least in a cross-sectional analysis). Steatosis is not per se harmful and can even be protective, questioning the therapeutic potential of modulating dSLs in the treatment of NASH. Nevertheless, reducing steatosis can be a target for NAFLD treatment, given the presumed role of lipotoxicity. The exact potential impact of modulating sphingolipid metabolism on NASH progression is hence to be determined.

In this study, patients were not included based on a a priori suspicion of liver disease .This selection procedure resulted in a series representing the whole spectrum of NAFLD, whereas retrospective series of biopsy proven NAFLD patients tend to be skewed towards more severe subtypes. On the other hand, analysis was performed cross-sectionally on a population that is predominantly Caucasian. A causal link between deoxy-sphingolipids and steatosis is therefore difficult to determine. Finally, the reported data only handles the sphingoid base concentrations. Although they reflect the total sphingoid base composition for all the individual sphingolipid subclasses, further investigation of these different subclasses is needed to provide a more detailed understanding of the pathological role of 
406 the sphingolipidome in NAFLD and its potential role in the development of therapeutic 407 agents.

408 Conclusion: dSLS are increased in relation to steatosis independently of their correlation 409 with metabolic markers, but are not further increased when the spectrum of NAFLD 410 worsens, questioning their role as a therapeutic target for NASH. 
413

414

415

416

417

418

419

420

421

422

423

424

425

426

427

428

429

430

431

432

433

434

435

436

437

438

439

440

441

442

443

444

445

446

447

448

449

450

451

452

453

454

455

456

457

458

459

460

1. Caldwell, S. and C. Argo, The natural history of non-alcoholic fatty liver disease. Dig Dis, 2010. 28(1): p. 162-8.

2. Caligiuri, A., A. Gentilini, and F. Marra, Molecular Pathogenesis of NASH. Int J Mol Sci, 2016. 17(9).

3. Angulo, P., et al., Liver Fibrosis, but No Other Histologic Features, Is Associated With Longterm Outcomes of Patients With Nonalcoholic Fatty Liver Disease. Gastroenterology, 2015. 149(2): p. 389-97.e10.

4. $\quad$ Ekstedt, M., et al., Fibrosis stage is the strongest predictor for disease-specific mortality in NAFLD after up to 33 years of follow-up. Hepatology, 2015. 61(5): p. 1547-54.

5. Hannun, Y.A. and L.M. Obeid, Sphingolipids and their metabolism in physiology and disease. Nat Rev Mol Cell Biol, 2018. 19(3): p. 175-191.

6. Bode, H., et al., HSAN1 mutations in serine palmitoyltransferase reveal a close structurefunction-phenotype relationship. Hum Mol Genet, 2016. 25(5): p. 853-65.

7. Nikolova-Karakashian, M., Sphingolipids at the Crossroads of NAFLD and Senescence. Adv Cancer Res, 2018. 140: p. 155-190.

8. Quehenberger, O., et al., Lipidomics reveals a remarkable diversity of lipids in human plasma. J Lipid Res, 2010. 51(11): p. 3299-305.

9. Bertea, M., et al., Deoxysphingoid bases as plasma markers in diabetes mellitus. Lipids Health Dis, 2010. 9: p. 84.

10. Zuellig, R.A., et al., Deoxysphingolipids, novel biomarkers for type 2 diabetes, are cytotoxic for insulin-producing cells. Diabetes, 2014. 63(4): p. 1326-39.

11. Mikolasevic, I., et al., Nonalcoholic fatty liver disease - A multisystem disease? World J Gastroenterol, 2016. 22(43): p. 9488-9505.

12. Verrijken, A., et al., Prothrombotic factors in histologically proven nonalcoholic fatty liver disease and nonalcoholic steatohepatitis. Hepatology, 2014. 59(1): p. 121-9.

13. Kleiner, D.E., et al., Design and validation of a histological scoring system for nonalcoholic fatty liver disease. Hepatology, 2005. 41(6): p. 1313-21.

14. Bedossa, P., Utility and appropriateness of the fatty liver inhibition of progression (FLIP) algorithm and steatosis, activity, and fibrosis (SAF) score in the evaluation of biopsies of nonalcoholic fatty liver disease. Hepatology, 2014. 60(2): p. 565-75.

15. Penno, A., et al., Hereditary sensory neuropathy type 1 is caused by the accumulation of two neurotoxic sphingolipids. J Biol Chem, 2010. 285(15): p. 11178-87.

16. Othman, A., et al., Plasma deoxysphingolipids: a novel class of biomarkers for the metabolic syndrome? Diabetologia, 2012. 55(2): p. 421-31.

17. Gorden, D.L., et al., Biomarkers of NAFLD progression: a lipidomics approach to an epidemic. J Lipid Res, 2015. 56(3): p. 722-36.

18. Gai, Z., et al., Farnesoid $X$ receptor activation induces the degradation of hepatotoxic 1deoxysphingolipids in non-alcoholic fatty liver disease. Liver Int, 2020. 40(4): p. 844-859.

19. Othman, A., et al., Plasma 1-deoxysphingolipids are predictive biomarkers for type 2 diabetes mellitus. BMJ Open Diabetes Res Care, 2015. 3(1): p. e000073.

20. Othman, A., et al., Fenofibrate lowers atypical sphingolipids in plasma of dyslipidemic patients: A novel approach for treating diabetic neuropathy? J Clin Lipidol, 2015. 9(4): p. 56875.

21. Othman, A., et al., Lowering plasma 1-deoxysphingolipids improves neuropathy in diabetic rats. Diabetes, 2015. 64(3): p. 1035-45.

22. Garofalo, K., et al., Oral L-serine supplementation reduces production of neurotoxic deoxysphingolipids in mice and humans with hereditary sensory autonomic neuropathy type 1. J Clin Invest, 2011. 121(12): p. 4735-45. 
Tables

Table 1: Patients characteristics according to the histology-based classification

\begin{tabular}{|c|c|c|c|c|c|c|c|}
\hline & \multirow{3}{*}{$\begin{array}{c}\text { TOTAL } \\
\text { N=288 } \\
(100 \%) \\
\mathbf{4 3 . 8} \\
( \pm 12.3)\end{array}$} & \multirow{3}{*}{$\begin{array}{l}\text { No-NAFL } \\
\begin{array}{c}\mathrm{N}=51(17.7 \%) \\
\mathbf{3 8 . 1} \\
( \pm 10.6)\end{array}\end{array}$} & \multirow{3}{*}{$\begin{array}{l}\text { NAFL } \\
\begin{array}{c}\mathrm{N}=47(16.3 \%) \\
\mathbf{4 3 . 5} \\
( \pm \mathbf{1 2 . 3})\end{array}\end{array}$} & \multirow{3}{*}{ 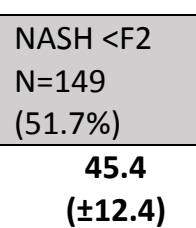 } & \multirow{3}{*}{$\begin{array}{c}\text { NASH } \geq F 2 \\
N=41 \\
(14.3 \%) \\
45.0 \\
( \pm 12.4)\end{array}$} & \multirow{3}{*}{$\begin{array}{l}p \text {-value } \\
0.003^{*}\end{array}$} \\
\hline & & & & & & & \\
\hline \multirow{2}{*}{ General } & $\begin{array}{l}\text { Age } \\
\text { (years) }\end{array}$ & & & & & & \\
\hline & $\begin{array}{l}\text { Gender: } \\
\text { men }\end{array}$ & $\begin{array}{c}96 \\
(33.3 \%)\end{array}$ & $\begin{array}{c}8 \\
(15.7 \%)\end{array}$ & $\begin{array}{c}10 \\
(21.3 \%)\end{array}$ & $\begin{array}{c}53 \\
(35.6 \%)\end{array}$ & $\begin{array}{c}25 \\
(61.0 \%)\end{array}$ & $<0.001^{* * *}$ \\
\hline \multirow{2}{*}{$\begin{array}{l}\text { Anthropometr } \\
\text { y }\end{array}$} & $\begin{array}{l}\mathrm{BMI} \\
\left(\mathrm{kg} / \mathrm{m}^{2}\right)\end{array}$ & $\begin{array}{c}39.6 \\
( \pm 6.4)\end{array}$ & $\begin{array}{c}38.2 \\
( \pm 4.9)\end{array}$ & $\begin{array}{c}39.9 \\
( \pm 7.1)\end{array}$ & $\begin{array}{c}38.9 \\
( \pm 6.0)\end{array}$ & $\begin{array}{c}43.5 \\
( \pm 7.4)\end{array}$ & $0.001^{* *}$ \\
\hline & $\begin{array}{l}\text { Waist } \\
\text { (cm) }\end{array}$ & $\begin{array}{c}118.8 \\
( \pm 13.2)\end{array}$ & $\begin{array}{l}111.93 \\
( \pm 10.4)\end{array}$ & $\begin{array}{c}118.1 \\
( \pm 13.6)\end{array}$ & $\begin{array}{c}117.9 \\
( \pm 11.3)\end{array}$ & $\begin{array}{c}132.1 \\
( \pm 13.1)\end{array}$ & $<0.001^{* *}$ \\
\hline \multirow{9}{*}{$\begin{array}{l}\text { Metabolic } \\
\text { markers }\end{array}$} & $\begin{array}{l}\text { TG } \\
(\mathrm{mg} / \mathrm{dL})\end{array}$ & $\begin{array}{c}155.5 \\
( \pm 78.5)\end{array}$ & $\begin{array}{c}137.2 \\
( \pm 66.6)\end{array}$ & $\begin{array}{c}150.3 \\
( \pm 106.9)\end{array}$ & $\begin{array}{c}157.1 \\
( \pm 72.8)\end{array}$ & $\begin{array}{c}177.9 \\
( \pm 69.4)\end{array}$ & $0.009^{* *}$ \\
\hline & $\begin{array}{l}\mathrm{LDL}-\mathrm{C} \\
(\mathrm{mg} / \mathrm{dL})\end{array}$ & $\begin{array}{c}124.7 \\
( \pm 36.8)\end{array}$ & $\begin{array}{c}121.5 \\
( \pm 43.9)\end{array}$ & $\begin{array}{c}128.8 \\
( \pm 33.2)\end{array}$ & $\begin{array}{c}123.4 \\
( \pm 35.7)\end{array}$ & $\begin{array}{c}128.5 \\
( \pm 35.5)\end{array}$ & $0.674^{*}$ \\
\hline & $\begin{array}{l}\text { HDL-C } \\
(\mathrm{mg} / \mathrm{dL})\end{array}$ & $\begin{array}{c}48.9 \\
( \pm 13.7)\end{array}$ & $\begin{array}{c}53.2 \\
( \pm 13.4)\end{array}$ & $\begin{array}{c}51.3 \\
( \pm 15.9)\end{array}$ & $\begin{array}{c}48.6 \\
( \pm 13.5)\end{array}$ & $\begin{array}{c}41.9 \\
( \pm 9.3)\end{array}$ & $<0.001^{* *}$ \\
\hline & $\begin{array}{l}\text { Statin } \\
\text { use (\%) }\end{array}$ & $\begin{array}{c}30 \\
(10.4) \\
\end{array}$ & $\begin{array}{c}2 \\
(3.9) \\
\end{array}$ & $\begin{array}{c}3 \\
(6.4) \\
\end{array}$ & $\begin{array}{c}22 \\
(14.8) \\
\end{array}$ & $\begin{array}{c}3 \\
(7.3) \\
\end{array}$ & $0.087^{* * *}$ \\
\hline & $\begin{array}{l}\text { HbA1c } \\
\text { (\%) }\end{array}$ & $\begin{array}{c}5.7 \\
( \pm 0.5) \\
\end{array}$ & $\begin{array}{c}5.4 \\
(0.3) \\
\end{array}$ & $\begin{array}{c}5.6 \\
( \pm 0.3) \\
\end{array}$ & $\begin{array}{c}5.6 \\
( \pm 0.4) \\
\end{array}$ & $\begin{array}{c}6.1 \\
( \pm 1.0) \\
\end{array}$ & $<0.001^{* *}$ \\
\hline & $\begin{array}{l}\text { Glucose } \\
\mathrm{mg} / \mathrm{dL}\end{array}$ & $\begin{array}{c}86.2 \\
( \pm 22.4)\end{array}$ & $\begin{array}{c}80.2 \\
( \pm 7.4)\end{array}$ & $\begin{array}{c}82.4 \\
( \pm 11.0)\end{array}$ & $\begin{array}{c}85.1 \\
( \pm 12.4)\end{array}$ & $\begin{array}{c}102.1 \\
( \pm 49.8)\end{array}$ & $<0.001^{* *}$ \\
\hline & $\begin{array}{l}\text { HOMA- } \\
\text { IR }\end{array}$ & $\begin{array}{c}4.0 \\
( \pm 3.2)\end{array}$ & $\begin{array}{c}3.1 \\
( \pm 3.2)\end{array}$ & $\begin{array}{c}2.9 \\
( \pm 1.8)\end{array}$ & $\begin{array}{c}3.8 \\
( \pm 2.4)\end{array}$ & $\begin{array}{c}6.8 \\
( \pm 5.1)\end{array}$ & $<0.001^{* *}$ \\
\hline & MetS & $\begin{array}{c}155 \\
(56.2 \%)\end{array}$ & $\begin{array}{c}20 \\
(40.8 \%)\end{array}$ & $\begin{array}{c}17 \\
(37.8 \%)\end{array}$ & $\begin{array}{c}87 \\
(61.3 \%)\end{array}$ & $\begin{array}{c}31 \\
(77.5 \%)\end{array}$ & $<0.001^{* * *}$ \\
\hline & T2DM & $\begin{array}{c}30 \\
(10.5 \%) \\
\end{array}$ & $\begin{array}{c}1 \\
(2.0 \%)\end{array}$ & $\begin{array}{c}3 \\
(6.5 \%) \\
\end{array}$ & $\begin{array}{c}16 \\
(10.9 \%) \\
\end{array}$ & $\begin{array}{c}10 \\
(24.4 \%) \\
\end{array}$ & $0.004^{* * *}$ \\
\hline \multirow{2}{*}{ Liver enzymes } & $\begin{array}{l}\text { AST } \\
\text { (U/L) }\end{array}$ & $\begin{array}{c}31.7 \\
( \pm 17.5)\end{array}$ & $\begin{array}{c}24.4 \\
( \pm 8.0)\end{array}$ & $\begin{array}{c}25.5 \\
( \pm 8.5)\end{array}$ & $\begin{array}{c}30.7 \\
( \pm 11.8)\end{array}$ & $\begin{array}{c}51.5 \\
( \pm 31.5)\end{array}$ & $<0.001^{* *}$ \\
\hline & $\begin{array}{l}\text { ALT } \\
\text { (U/L) }\end{array}$ & $\begin{array}{c}45.6 \\
( \pm 27.3) \\
\end{array}$ & $\begin{array}{c}31.0 \\
( \pm 11.3)\end{array}$ & $\begin{array}{c}36.1 \\
( \pm 18.7)\end{array}$ & $\begin{array}{c}45.8 \\
( \pm 21.6) \\
\end{array}$ & $\begin{array}{c}74.0 \\
( \pm 43.0)\end{array}$ & $<0.001^{* *}$ \\
\hline \multirow{8}{*}{$\begin{array}{l}\text { Sphingoid } \\
\text { bases }\end{array}$} & $\mathrm{C}_{16}-\mathrm{SA}$ & $\begin{array}{c}0.469 \\
( \pm 0.221)\end{array}$ & $\begin{array}{c}0.460 \\
( \pm 0.227)\end{array}$ & $\begin{array}{c}0.441 \\
( \pm 0.159)\end{array}$ & $\begin{array}{c}0.491 \\
( \pm 0.249)\end{array}$ & $\begin{array}{c}0.432 \\
( \pm 0.156)\end{array}$ & $0.673^{* *}$ \\
\hline & $\mathrm{C}_{16}-\mathrm{SO}$ & $\begin{array}{c}15.491 \\
( \pm 5.313)\end{array}$ & $\begin{array}{c}15.991 \\
( \pm 5.880)\end{array}$ & $\begin{array}{c}16.584 \\
( \pm 4.753)\end{array}$ & $\begin{array}{c}15.379 \\
( \pm 5.568)\end{array}$ & $\begin{array}{c}14.026 \\
( \pm 3.828)\end{array}$ & $0.067^{* *}$ \\
\hline & $\mathrm{C}_{17}-\mathrm{SO}$ & $\begin{array}{c}6.233 \\
( \pm 2.007) \\
\end{array}$ & $\begin{array}{c}6.533 \\
( \pm 2.365) \\
\end{array}$ & $\begin{array}{c}6.665 \\
( \pm 1.686) \\
\end{array}$ & $\begin{array}{c}6.180 \\
( \pm 2.053) \\
\end{array}$ & $\begin{array}{c}5.555 \\
( \pm 1.498) \\
\end{array}$ & $0.018^{* *}$ \\
\hline & $\mathrm{C}_{18} \mathrm{SA}$ & $\begin{array}{c}3.659 \\
( \pm 1.401) \\
\end{array}$ & $\begin{array}{c}3.599 \\
( \pm 1.588) \\
\end{array}$ & $\begin{array}{c}3.512 \\
( \pm 1.229) \\
\end{array}$ & $\begin{array}{c}3.726 \\
( \pm 1.459) \\
\end{array}$ & $\begin{array}{c}3.662 \\
( \pm 1.126) \\
\end{array}$ & $0.822^{*}$ \\
\hline & $\mathrm{C}_{18} \mathrm{-SO}$ & $\begin{array}{c}84.161 \\
( \pm 20.682)\end{array}$ & $\begin{array}{c}86.927 \\
( \pm 24.394)\end{array}$ & $\begin{array}{c}89.051 \\
( \pm 17.530) \\
\end{array}$ & $\begin{array}{c}83.308 \\
( \pm 21.246) \\
\end{array}$ & $\begin{array}{c}78.050 \\
( \pm 14.864)\end{array}$ & $0.008^{* *}$ \\
\hline & $\begin{array}{l}\mathrm{C}_{18^{-}} \\
\text {phytoS } \\
\mathrm{O}\end{array}$ & $\begin{array}{c}0.110 \\
( \pm 0.038)\end{array}$ & $\begin{array}{c}0.115 \\
( \pm 0.052)\end{array}$ & $\begin{array}{c}0.114 \\
( \pm 0.029)\end{array}$ & $\begin{array}{c}0.110 \\
( \pm 0.037)\end{array}$ & $\begin{array}{c}0.100 \\
( \pm 0.026)\end{array}$ & $0.135^{* *}$ \\
\hline & $\mathrm{C}_{19}-\mathrm{SO}$ & $\begin{array}{c}1.815 \\
( \pm 0.794)\end{array}$ & $\begin{array}{c}1.875 \\
( \pm 0.839)\end{array}$ & $\begin{array}{c}1.814 \\
( \pm 0.702)\end{array}$ & $\begin{array}{c}1.871 \\
( \pm 0.858)\end{array}$ & $\begin{array}{c}1.541 \\
( \pm 0.508)\end{array}$ & $0.200^{* *}$ \\
\hline & $\mathrm{C}_{20}-\mathrm{SA}$ & $\begin{array}{c}0.024 \\
( \pm 0.108)\end{array}$ & $\begin{array}{c}0.021 \\
( \pm 0.010)\end{array}$ & $\begin{array}{c}0.024 \\
( \pm 0.012)\end{array}$ & $\begin{array}{c}0.025 \\
( \pm 0.110)\end{array}$ & $\begin{array}{c}0.025 \\
( \pm 0.009)\end{array}$ & $0.024^{* *}$ \\
\hline
\end{tabular}




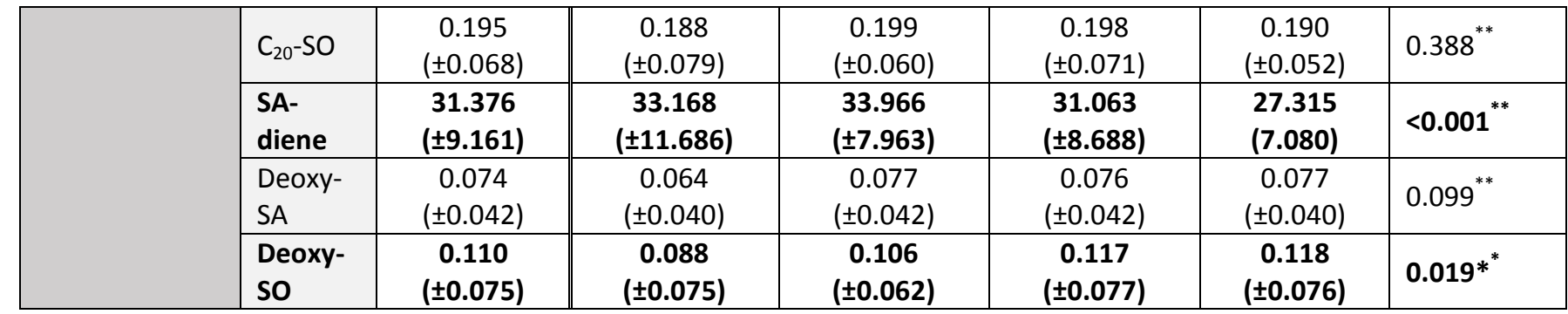

No histological evidence of Non-Alcoholic Fatty Liver Disease (No-NAFLD), Non-Alcoholic Fatty Liver (NAFL), Non-Alcoholic Steatohepatitis with no significant fibrosis (NASH <F2), Non-Alcoholic Steatohepatitis with significant fibrosis (NASH $\geq F 2$ ), Body mass index (BMI), Triglycerides (TG), Low density lipoprotein cholesterol (LLD-C), High density lipoprotein cholesterol (HDL-C), Haemoglobin $A_{1 c}\left(H b A_{1 C}\right)$, Homeostatic model assessment insulin resistance (HOMA-IR), Metabolic syndrome (MetS), aspartate aminotransferase (AST), alanine aminotransferase (ALT), $C_{16^{-}}$Sphinganine $\left(C_{16^{-}}\right.$SA), $C_{16^{-}}$Sphingosine $\left(C_{16^{-}}\right.$SO), $C_{17^{-}}$-Sphingosine $\left(C_{17^{-}}-S O\right), C_{18^{-}}$ Sphinganine $\left(C_{18^{-}} S A\right), C_{18}$-Sphingosine $\left(C_{18}-S O\right), C_{19}$-Sphingosine $\left(C_{19}-S O\right), C_{20}$-Sphinganine $\left(C_{20^{-}} S A\right), C_{20^{-}}$ Sphingosine ( $\left.C_{20}-S O\right)$, Sphingadiene (SA-diene), $C_{18}$-phyto-sphingosine ( $C_{18}$-phyto-SO), deoxy-sphinganine (deoxy-SA), deoxy-sphingosine (deoxy-SO). SD or percentage of the total group is presented between brackets. p-values: *ANOVA, ${ }^{* *}$ Kruskal-Wallis, ${ }^{* * *}$ Pearson Chi-square.

Table 2: Correlation with metabolic and inflammatory parameters

\begin{tabular}{|l|l|l|l|l|}
\cline { 2 - 5 } \multicolumn{2}{|l|}{} & \multicolumn{2}{l|}{ Triglycerides } & \multicolumn{2}{l|}{ HOMA-IR } \\
\cline { 2 - 5 } \multicolumn{1}{l|}{ Correlation coefficient* } & $\mathrm{p}$ & Correlation coefficient* & $\mathrm{p}$ \\
\hline Deoxy-SA & $\mathbf{0 . 5 5 3}$ & $<0.001$ & $\mathbf{0 . 1 3 8}$ & $\mathbf{0 . 0 2 1}$ \\
\hline Deoxy-SO & $\mathbf{0 . 5 8 1}$ & $<0.001$ & 0.104 & 0.081 \\
\hline
\end{tabular}

* Spearman's rho. Homeostatic model assessment insulin resistance (HOMA-IR), deoxy-sphinganine (deoxy-SA) deoxy-sphingosine (deoxy-SO) 


\section{Supplementary materials}

Supplementary Table 1: Patient characteristics for the comparison No-NAFLD vs. NAFL

\begin{tabular}{|c|c|c|c|c|}
\hline & & $\begin{array}{c}\text { No-NAFLD } \\
\mathrm{N}=51\end{array}$ & $\begin{array}{l}\text { NAFL } \\
N=47\end{array}$ & $\mathrm{p}$ \\
\hline \multirow{2}{*}{ General } & Age (years) & $38.1( \pm 10.6)$ & $43.5( \pm 12.3)$ & $0.021^{* *}$ \\
\hline & Gender: men & $8(15.7 \%)$ & $10(21.3 \%)$ & $0.475^{* * *}$ \\
\hline \multirow{2}{*}{ Anthropometry } & BMI $\left(\mathrm{kg} / \mathrm{m}^{2}\right)$ & $38.2( \pm 4.9)$ & $39.9( \pm 7.1)$ & $0.190^{* *}$ \\
\hline & Waist $(\mathrm{cm})$ & $111.93( \pm 10.4)$ & $118.1( \pm 13.6)$ & $0.007^{* *}$ \\
\hline \multirow{9}{*}{$\begin{array}{l}\text { Metabolic } \\
\text { markers }\end{array}$} & TG (mg/dL) & $137.2( \pm 66.6)$ & $150.3( \pm 106.9)$ & $0.814^{*}$ \\
\hline & $\begin{array}{l}\text { LDL-C } \\
(\mathrm{mg} / \mathrm{dL})\end{array}$ & $121.5( \pm 43.9)$ & $128.8( \pm 33.2)$ & $0.369^{* *}$ \\
\hline & $\begin{array}{l}\text { HDL-C } \\
(\mathrm{mg} / \mathrm{dL})\end{array}$ & $53.2( \pm 13.4)$ & $51.3( \pm 15.9)$ & $0.415^{*}$ \\
\hline & $\begin{array}{l}\text { Statin use } \\
(\%)\end{array}$ & $2(3.9)$ & $3(6.4)$ & $0.580^{* * *}$ \\
\hline & HbA1c (\%) & $5.4(0.3)$ & $5.6( \pm 0.3)$ & $<0.001^{*}$ \\
\hline & $\begin{array}{l}\text { Glucose } \\
(\mathrm{mg} / \mathrm{dL})\end{array}$ & $80.2( \pm 7.4)$ & $82.4( \pm 11.0)$ & $0.611^{*}$ \\
\hline & HOMA-IR & $3.1( \pm 3.2)$ & $2.9( \pm 1.8)$ & $0.652^{*}$ \\
\hline & MetS & $20(40.8 \%)$ & $17(37.8 \%)$ & $0.763^{* * *}$ \\
\hline & T2DM & $1(2.0 \%)$ & $3(6.5 \%)$ & $0.259^{* * *}$ \\
\hline \multirow{2}{*}{ Liver enzymes } & AST (U/L) & $24.4( \pm 8.0)$ & $25.5( \pm 8.5)$ & $0.254^{*}$ \\
\hline & $\operatorname{ALT}(\mathrm{U} / \mathrm{L})$ & $31.0( \pm 11.3)$ & $36.1( \pm 18.7)$ & $0.248^{*}$ \\
\hline Imaging & $\begin{array}{l}\text { Steatosis on } \\
\text { US }\end{array}$ & $30(61.2 \%)$ & $40(95.2 \%)$ & $<0.001^{* * *}$ \\
\hline \multirow{4}{*}{ Pathology } & $\begin{array}{l}\text { Steatosis } \\
0 / 1 / 2 / 3(\%)\end{array}$ & $100 / 0.0 / 0.0 / 0.0$ & $0.0 / 80.9 / 17.0 / 2.1$ & $<0.001^{* * *}$ \\
\hline & $\begin{array}{l}\text { Ballooning } \\
0 / 1 / 2(\%)\end{array}$ & $100 / 0.0 / 0.0$ & $68.1 / 31.9 / 0.0$ & $<0.001^{* * *}$ \\
\hline & $\begin{array}{l}\text { Inflammatio } \\
\text { n } 0 / 1 / 2 \text { (\%) }\end{array}$ & $100 / 0.0 / 0.0$ & $72.3 / 27.3 / 0.0$ & $<0.001^{* * *}$ \\
\hline & $\begin{array}{l}\text { Fibrosis } \\
0 / 1 / 2 / 3 / 4 \\
(\%)\end{array}$ & $100 / 0.0 / 0.0 / 0.0 / 0.0$ & $93.6 / 6.4 / 0.0 / 0.0 / 0.0$ & $0.067^{* * *}$ \\
\hline \multirow{9}{*}{$\begin{array}{l}\text { Sphingoid } \\
\text { bases }\end{array}$} & $\mathrm{C}_{16}-\mathrm{SA}$ & $0.460( \pm 0.227)$ & $0.441( \pm 0.159)$ & $0.890^{*}$ \\
\hline & $\mathrm{C}_{16}-\mathrm{SO}$ & $15.991( \pm 5.880)$ & $16.584( \pm 4.753)$ & $0.384^{*}$ \\
\hline & $\mathrm{C}_{17}-\mathrm{SO}$ & $6.533( \pm 2.365)$ & $6.665( \pm 1.686)$ & $0.384^{*}$ \\
\hline & $\mathrm{C}_{18} \mathrm{SA}$ & $3.599( \pm 1.588)$ & $3.512( \pm 1.229)$ & $0.773^{*}$ \\
\hline & $\mathrm{C}_{18}$-SO & $86.927( \pm 24.394)$ & $89.051( \pm 17.530)$ & $0.328^{*}$ \\
\hline & $\mathrm{C}_{18}$-phytoSO & $0.115( \pm 0.052)$ & $0.114( \pm 0.029)$ & $0.526^{* *}$ \\
\hline & $\mathrm{C}_{19}-\mathrm{SO}$ & $1.875( \pm 0.839)$ & $1.814( \pm 0.702)$ & $0.897^{* *}$ \\
\hline & $\mathrm{C}_{20}-\mathrm{SA}$ & $0.021( \pm 0.010)$ & $0.024( \pm 0.012)$ & $0.236^{*}$ \\
\hline & $\mathrm{C}_{20}-\mathrm{SO}$ & $0.188( \pm 0.079)$ & $0.199( \pm 0.060)$ & $0.281^{* *}$ \\
\hline
\end{tabular}




\begin{tabular}{|l|l|c|c|c|}
\hline & SA-diene & $33.168( \pm 11.686)$ & $33.966( \pm 7.963)$ & $0.387^{* *}$ \\
\cline { 2 - 5 } & Deoxy-SA & $\mathbf{0 . 0 6 4 ( \pm 0 . 0 4 0 )}$ & $\mathbf{0 . 0 7 7}( \pm \mathbf{0 . 0 4 2})$ & $\mathbf{0 . 0 2 3}^{* *}$ \\
\cline { 2 - 5 } & Deoxy-SO & $\mathbf{0 . 0 8 8 ( \pm 0 . 0 7 5 )}$ & $\mathbf{0 . 1 0 6 ( \pm 0 . 0 6 2 )}$ & $\mathbf{0 . 0 1 4 ^ { * * }}$ \\
\hline
\end{tabular}

* Mann-Whitney $\mathrm{U},{ }^{* *}$ independent sample T-test, ${ }^{* * *}$ chi-square. Ballooning and Inflammation are graded according to SAF/Flip-algorithm. No histological evidence of Non-Alcoholic Fatty Liver Disease (no-NAFLD), Non-Alcoholic Fatty Liver (NAFL), Significant fibrosis ( $\geq$ F2), Body mass index (BMI), Triglycerides (TG), Low density lipoprotein cholesterol (LLD-C), High density lipoprotein cholesterol (HDL-C), Haemoglobin $A_{1 c}\left(H_{b} A_{1 c}\right)$, Homeostatic model assessment insulin resistance (HOMA-IR), Metabolic syndrome (MetS), aspartate aminotransferase (AST), alanine aminotransferase (ALT), $C_{16}$-Sphinganine $\left(\mathrm{C}_{16}-\mathrm{SA}\right), \mathrm{C}_{16}$-Sphingosine $\left(\mathrm{C}_{16}\right.$-SO), $\mathrm{C}_{17}$-Sphingosine $\left(\mathrm{C}_{17}-\mathrm{SO}\right), \mathrm{C}_{18}$-Sphinganine $\left(\mathrm{C}_{18}-\mathrm{SA}\right), \mathrm{C}_{18}$-Sphingosine $\left(\mathrm{C}_{18}-\mathrm{SO}\right), \mathrm{C}_{19}$-Sphingosine $\left(\mathrm{C}_{19^{-}} \mathrm{SO}\right), \mathrm{C}_{20^{-}}$ Sphinganine $\left(\mathrm{C}_{20}-\mathrm{SA}\right), \mathrm{C}_{20}$-Sphingosine ( $\left.\mathrm{C}_{20}-\mathrm{SO}\right)$, Sphingadiene (SA-diene), $\mathrm{C}_{18}$-phyto-sphingosine ( $\mathrm{C}_{18}$-phyto-SO), deoxy-sphinganine (deoxy-SA), deoxy-sphingosine (deoxy-SO). SD or percentage of the total group is presented between brackets.

Supplementary Table 2: patient characteristics for the comparison NAFL vs. NASH

\begin{tabular}{|c|c|c|c|c|}
\hline & & $\begin{array}{l}\text { NAFL } \\
N=47\end{array}$ & $\begin{array}{c}\mathrm{NASH}<\mathrm{F} 2 \\
\mathrm{~N}=149\end{array}$ & $\mathrm{p}$ \\
\hline \multirow{2}{*}{ General } & Age (years) & $43.5( \pm 12.3)$ & $45.4( \pm 12.4)$ & $0.350^{* *}$ \\
\hline & Gender: men & 10 (21.3\%) & 53 (35.6\%) & $0.067^{* * *}$ \\
\hline \multirow{2}{*}{ Anthropometry } & BMI $\left(\mathrm{kg} / \mathrm{m}^{2}\right)$ & $39.9( \pm 7.1)$ & $38.9( \pm 6.0)$ & $0.486^{*}$ \\
\hline & Waist $(\mathrm{cm})$ & $118.1( \pm 13.6)$ & $117.9( \pm 11.3)$ & $0.952^{* *}$ \\
\hline \multirow{9}{*}{$\begin{array}{l}\text { Metabolic } \\
\text { markers }\end{array}$} & TG (mg/dL) & $150.3( \pm 106.9)$ & $157.1( \pm 72.8)$ & $0.113^{*}$ \\
\hline & $\begin{array}{l}\text { LDL-C } \\
(\mathrm{mg} / \mathrm{dL})\end{array}$ & $128.8( \pm 33.2)$ & $123.4( \pm 35.7)$ & $0.373^{* *}$ \\
\hline & $\begin{array}{l}\text { HDL-C } \\
\text { (mg/dL) }\end{array}$ & $51.3( \pm 15.9)$ & $48.6( \pm 13.5)$ & $0.285^{*}$ \\
\hline & Statin use (\%) & $3(6.4)$ & $22(14.8)$ & $0.133^{* * *}$ \\
\hline & HbA1c (\%) & $5.6( \pm 0.3)$ & $5.6( \pm 0.4)$ & $0.514^{*}$ \\
\hline & $\begin{array}{l}\text { Glucose } \\
\text { (mg/dL) }\end{array}$ & $82.4( \pm 11.0)$ & $85.1( \pm 12.4)$ & $0.151^{*}$ \\
\hline & HOMA-IR & $2.9( \pm 1.8)$ & $3.8( \pm 2.4)$ & $0.026^{*}$ \\
\hline & MetS & $17(37.8 \%)$ & 87 (61.3\%) & $0.006^{* * *}$ \\
\hline & T2DM & $3(6.5 \%)$ & 16 (10.9\%) & $0.386^{* * *}$ \\
\hline \multirow{2}{*}{ Liver enzymes } & AST (U/L) & $25.5( \pm 8.5)$ & $30.7( \pm 11.8)$ & $0.005^{*}$ \\
\hline & ALT (U/L) & $36.1( \pm 18.7)$ & $45.8( \pm 21.6)$ & $0.001^{*}$ \\
\hline Imaging & $\begin{array}{l}\text { Steatosis on } \\
\text { US }\end{array}$ & 40 (95.2\%) & 139 (96.5\%) & $0.699^{* * *}$ \\
\hline \multirow[t]{3}{*}{ Pathology } & $\begin{array}{l}\text { Steatosis } \\
0 / 1 / 2 / 3(\%)\end{array}$ & $0.0 / 80.9 / 17.0 / 2.1$ & $0.0 / 36.9 / 38.3 / 24.8$ & $<0.001^{* * *}$ \\
\hline & $\begin{array}{l}\text { Ballooning } \\
0 / 1 / 2(\%)\end{array}$ & $68.1 / 31.9 / 0.0$ & $0.0 / 50.3 / 49.7$ & $<0.001^{* * *}$ \\
\hline & $\begin{array}{l}\text { Inflammation } \\
0 / 1 / 2(\%)\end{array}$ & $72.3 / 27.3 / 0.0$ & $0.0 / 58.4 / 41.6$ & $<0.001^{* *}$ \\
\hline
\end{tabular}




\begin{tabular}{|c|c|c|c|c|}
\hline & $\begin{array}{c}\text { Fibrosis } \\
0 / 1 / 2 / 3 / 4 \\
(\%)\end{array}$ & $93.6 / 6.4 / 0.0 / 0.0 / 0.0$ & $70.5 / 29.5 / 0.0 / 0.0 / 0.0$ & $0.001^{* * *}$ \\
\hline \multirow{12}{*}{$\begin{array}{l}\text { Sphingoid } \\
\text { bases }\end{array}$} & $\mathrm{C}_{16}-\mathrm{SA}$ & $0.434( \pm 0.141)$ & $0.478( \pm 0.233)$ & $0.469^{*}$ \\
\hline & $\mathrm{C}_{16}-\mathrm{SO}$ & $16.212( \pm 4.426)$ & $15.087( \pm 5.262)$ & $0.031^{*}$ \\
\hline & $\mathrm{C}_{17}-\mathrm{SO}$ & $6.511( \pm 1.610)$ & $6.045( \pm 1.960)$ & $0.023^{*}$ \\
\hline & $\mathrm{C}_{18}-\mathrm{SA}$ & $3.464( \pm 1.238)$ & $3.712( \pm 1.392)$ & $0.689^{*}$ \\
\hline & $\mathrm{C}_{18} \mathrm{-SO}$ & $86.492( \pm 17.300)$ & $82.173( \pm 20.123)$ & $0.005^{*}$ \\
\hline & $\mathrm{C}_{18}$-phytoSO & $0.111( \pm 0.029)$ & $0.108( \pm 0.035)$ & $0.229^{*}$ \\
\hline & $\mathrm{C}_{19}-\mathrm{SO}$ & $1.760( \pm 0.667)$ & $1.800( \pm 0.806)$ & $0.839^{* *}$ \\
\hline & $\mathrm{C}_{20} \mathrm{SA}$ & $0.023( \pm 0.011)$ & $0.025( \pm 0.010)$ & $0.315^{* *}$ \\
\hline & $\mathrm{C}_{20}-\mathrm{SO}$ & $0.194( \pm 0.060)$ & $0.196( \pm 0.067)$ & $0.773^{* *}$ \\
\hline & SA-diene & $32.700( \pm 7.803)$ & $30.254( \pm 8.491)$ & $0.028^{* *}$ \\
\hline & Deoxy-SA & $0.079( \pm 0.041)$ & $0.077( \pm 0.042)$ & $0.867^{* *}$ \\
\hline & Deoxy-SO & $0.115( \pm 0.075)$ & $0.117( \pm 0.077)$ & $0.441^{* *}$ \\
\hline
\end{tabular}

* Mann-Whitney $\mathrm{U},{ }^{* *}$ independent sample T-test, ${ }^{* * *}$ chi-square. Ballooning and Inflammation are graded according to SAF/Flip-algorithm. Non-Alcoholic Steatohepatitis with no significant fibrosis (NASH $<F 2$ ), NonAlcoholic Steatohepatitis with significant fibrosis (NASH $\geq F 2$ ), Body mass index (BMI), Triglycerides (TG), Low density lipoprotein cholesterol (LLD-C), High density lipoprotein cholesterol (HDL-C), Haemoglobin $\mathrm{A}_{1 \mathrm{c}}\left(\mathrm{HbA}_{1 \mathrm{c}}\right.$ ), Homeostatic model assessment insulin resistance (HOMA-IR), Metabolic syndrome (MetS), aspartate aminotransferase (AST), alanine aminotransferase (ALT), $\mathrm{C}_{16}$-Sphinganine $\left(\mathrm{C}_{16}-\mathrm{SA}\right), \mathrm{C}_{16}$-Sphingosine $\left(\mathrm{C}_{16}\right.$-SO), $\mathrm{C}_{17}$-Sphingosine ( $\mathrm{C}_{17}$-SO), $\mathrm{C}_{18}$-Sphinganine $\left(\mathrm{C}_{18}-\mathrm{SA}\right), \mathrm{C}_{18^{-}}$-Sphingosine $\left(\mathrm{C}_{18}-\mathrm{SO}\right), \mathrm{C}_{19}$-Sphingosine $\left(\mathrm{C}_{19}-\mathrm{SO}\right), \mathrm{C}_{20^{-}}$ Sphinganine $\left(\mathrm{C}_{20}-\mathrm{SA}\right), \mathrm{C}_{20}$-Sphingosine $\left(\mathrm{C}_{20}-\mathrm{SO}\right)$, Sphingadiene (SA-diene), $\mathrm{C}_{18}$-phyto-sphingosine ( $\mathrm{C}_{18}$-phyto-SO), deoxy-sphinganine (deoxy-SA), deoxy-sphingosine (deoxy-SO). SD or percentage of the total group is presented between brackets.

Supplementary Table 3: Patient characteristics for the comparison NASH $<F 2$ vs. NASH $\geq F 2$

\begin{tabular}{|c|c|c|c|c|}
\hline & & $\begin{array}{l}\mathrm{NASH}<\mathrm{F} 2 \\
\mathrm{~N}=149\end{array}$ & $\begin{array}{l}\mathrm{NASH} \geq \mathrm{F} 2 \\
\mathrm{~N}=41\end{array}$ & $\mathrm{p}$ \\
\hline \multirow{2}{*}{ General } & Age (years) & $45.4( \pm 12.4)$ & $45.0( \pm 12.4)$ & $0.855^{* *}$ \\
\hline & Gender: men & 53 (35.6\%) & 25 (61.0\%) & $0.003^{* * *}$ \\
\hline \multirow{2}{*}{ Anthropometry } & BMI $\left(\mathrm{kg} / \mathrm{m}^{2}\right)$ & $38.9( \pm 6.0)$ & $43.5( \pm 7.4)$ & $<0.001^{*}$ \\
\hline & Waist (cm) & $117.9( \pm 11.3)$ & $132.1( \pm 13.1)$ & $<0.001^{* *}$ \\
\hline \multirow{9}{*}{ Metabolic markers } & $\mathrm{TG}(\mathrm{mg} / \mathrm{dL})$ & $157.1( \pm 72.8)$ & $177.9( \pm 69.4)$ & $0.059^{*}$ \\
\hline & LDL-C (mg/dL) & $123.4( \pm 35.7)$ & $128.5( \pm 35.5)$ & $0.420^{* *}$ \\
\hline & HDL-C (mg/dL) & $48.6( \pm 13.5)$ & $41.9( \pm 9.3)$ & $0.002^{*}$ \\
\hline & Statin use (\%) & $22(14.8)$ & $3(7.3)$ & $0.212^{* * *}$ \\
\hline & HbA1c (\%) & $5.6( \pm 0.4)$ & $6.1( \pm 1.0)$ & $<0.001^{*}$ \\
\hline & Glucose $(\mathrm{mg} / \mathrm{dL})$ & $85.1( \pm 12.4)$ & $102.1( \pm 49.8)$ & $<0.001^{*}$ \\
\hline & HOMA-IR & $3.8( \pm 2.4)$ & $6.8( \pm 5.1)$ & $<0.001^{*}$ \\
\hline & MetS & $87(61.3 \%)$ & 31 (77.5\%) & $0.058^{* * *}$ \\
\hline & T2DM & 16 (10.9\%) & 10 (24.4\%) & $0.027^{* * *}$ \\
\hline Liver enzymes & AST (U/L) & $30.7( \pm 11.8)$ & $51.5( \pm 31.5)$ & $<0.001^{*}$ \\
\hline
\end{tabular}




\begin{tabular}{|c|c|c|c|c|}
\hline & ALT (U/L) & $45.8( \pm 21.6)$ & $74.0( \pm 43.0)$ & $<0.001^{*}$ \\
\hline Imaging & Steatosis on US & 139 (96.5\%) & $37( \pm 94.9)$ & $0.632^{* * *}$ \\
\hline \multirow{4}{*}{ Pathology } & $\begin{array}{l}\text { Steatosis } 0 / 1 / 2 / 3 \\
(\%)\end{array}$ & $0.0 / 36.9 / 38.3 / 24.8$ & $0.0 / 14.6 / 31.7 / 53.7$ & $0.001^{* * *}$ \\
\hline & Ballooning 0/1/2 (\%) & $0.0 / 50.3 / 49.7$ & $0.0 / 51.2 / 48.8$ & $0.920^{* * *}$ \\
\hline & $\begin{array}{l}\text { Inflammation } 0 / 1 / 2 \\
(\%)\end{array}$ & $0.0 / 58.4 / 41.6$ & $0.0 / 29.3 / 70.7$ & $<0.001^{* * *}$ \\
\hline & $\begin{array}{l}\text { Fibrosis } 0 / 1 / 2 / 3 / 4 \\
(\%)\end{array}$ & $70.5 / 29.5 / 0.0 / 0.0 / 0.0$ & $\begin{array}{c}0.0 / 0.0 / 58.5 / 39.0 / 2 \\
5 \\
\end{array}$ & $<0.001^{* * *}$ \\
\hline \multirow[t]{12}{*}{ Sphingoid bases } & $\mathrm{C}_{16}-\mathrm{SA}$ & $0.491( \pm 0.249)$ & $0.432( \pm 0.156)$ & $0.375^{*}$ \\
\hline & $\mathrm{C}_{16}-\mathrm{SO}$ & $15.379( \pm 5.568)$ & $14.026( \pm 3.838)$ & $0.206^{* *}$ \\
\hline & $\mathrm{C}_{17}-\mathrm{SO}$ & $6.180( \pm 2.053)$ & $5.555( \pm 1.498)$ & $0.083^{* *}$ \\
\hline & $\mathrm{C}_{18}$-SA & $3.726( \pm 1.459)$ & $3.662( \pm 1.126)$ & $0.687^{*}$ \\
\hline & $\mathrm{C}_{18}-\mathrm{SO}$ & $83.308( \pm 21.246)$ & $78.050( \pm 14.864)$ & $0.250^{*}$ \\
\hline & $\mathrm{C}_{18}$-phytoSO & $0.110( \pm 0.037)$ & $0.100( \pm 0.026)$ & $0.126^{*}$ \\
\hline & $\mathrm{C}_{19}-\mathrm{SO}$ & $1.871( \pm 0.858)$ & $1.541( \pm 0.508)$ & $0.046^{* *}$ \\
\hline & $\mathrm{C}_{20}-\mathrm{SA}$ & $0.025( \pm 0.011)$ & $0.026( \pm 0.009)$ & $0.528^{* *}$ \\
\hline & $\mathrm{C}_{20}-\mathrm{SO}$ & $0.198( \pm 0.071)$ & $0.190( \pm 0.052)$ & $0.958^{*}$ \\
\hline & SA-diene & $31.063( \pm 8.688)$ & $27.316(7.078)$ & $0.008^{* *}$ \\
\hline & Deoxy-SA & $0.077( \pm 0.042)$ & $0.077( \pm 0.040)$ & $0.832^{* *}$ \\
\hline & Deoxy-SO & $0.117( \pm 0.078)$ & $0.118( \pm 0.076)$ & $0.895^{* *}$ \\
\hline
\end{tabular}

* Mann-Whitney $\mathrm{U},{ }^{* *}$ independent sample T-test, *** chi-square. Ballooning and Inflammation are graded according to SAF/Flip-algorithm. Non-Alcoholic Steatohepatitis with no significant fibrosis (NASH <F2), NonAlcoholic Steatohepatitis with significant fibrosis (NASH $\geq$ F2), Body mass index (BMI), Triglycerides (TG), Low density lipoprotein cholesterol (LLD-C), High density lipoprotein cholesterol (HDL-C), Haemoglobin $A_{1 c}\left(H b A_{1 c}\right)$, Homeostatic model assessment insulin resistance (HOMA-IR), Metabolic syndrome (MetS), aspartate aminotransferase (AST), alanine aminotransferase (ALT), $C_{16}$-Sphinganine $\left(C_{16}-S A\right), C_{16}$-Sphingosine $\left(C_{16}\right.$-SO), $\mathrm{C}_{17}$-Sphingosine $\left(\mathrm{C}_{17}-\mathrm{SO}\right), \mathrm{C}_{18}$-Sphinganine $\left(\mathrm{C}_{18}-\mathrm{SA}\right), \mathrm{C}_{18}$-Sphingosine $\left(\mathrm{C}_{18}-\mathrm{SO}\right), \mathrm{C}_{19^{-}}$-Sphingosine $\left(\mathrm{C}_{19^{-}}-\mathrm{SO}\right), \mathrm{C}_{20^{-}}$ Sphinganine $\left(\mathrm{C}_{20}-\mathrm{SA}\right), \mathrm{C}_{20}$-Sphingosine $\left(\mathrm{C}_{20}-\mathrm{SO}\right)$, Sphingadiene (SA-diene), $\mathrm{C}_{18}$-phyto-sphingosine $\left(\mathrm{C}_{18}\right.$-phyto-SO), deoxy-sphinganine (deoxy-SA), deoxy-sphingosine (deoxy-SO). SD or percentage of the total group is presented between brackets. 


\section{Legends to the Figures}

Figure 1: Biosynthesis of sphingolipids and 1-deoxy-sphingolipids.

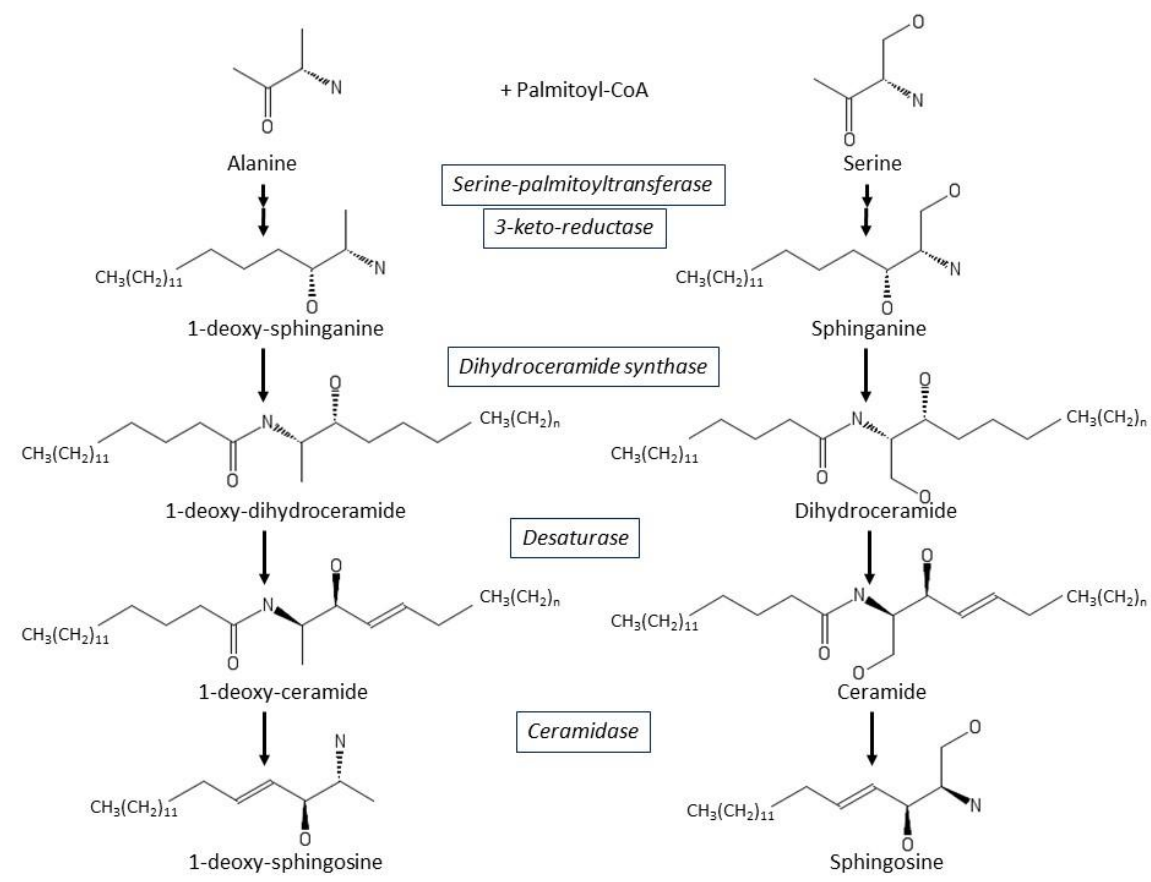

The enzyme serine-palmitoyltransferase (SPT) catalyses the first and rate-limiting step in the de novo synthesis of sphingolipids, which converts L-serine and palmitoyl-CoA into 3-ketosphinganine. The latter is converted into sphinganine (SA). SA is N-conjugated with another fatty acid to form dihydro-ceramide. When desaturated at $\mathrm{C} 4$ it forms ceramide. Ceramidase converts ceramide into sphingosine. 
Figure 2: Correlation of fasting plasma sphingoid bases and metabolic markers.
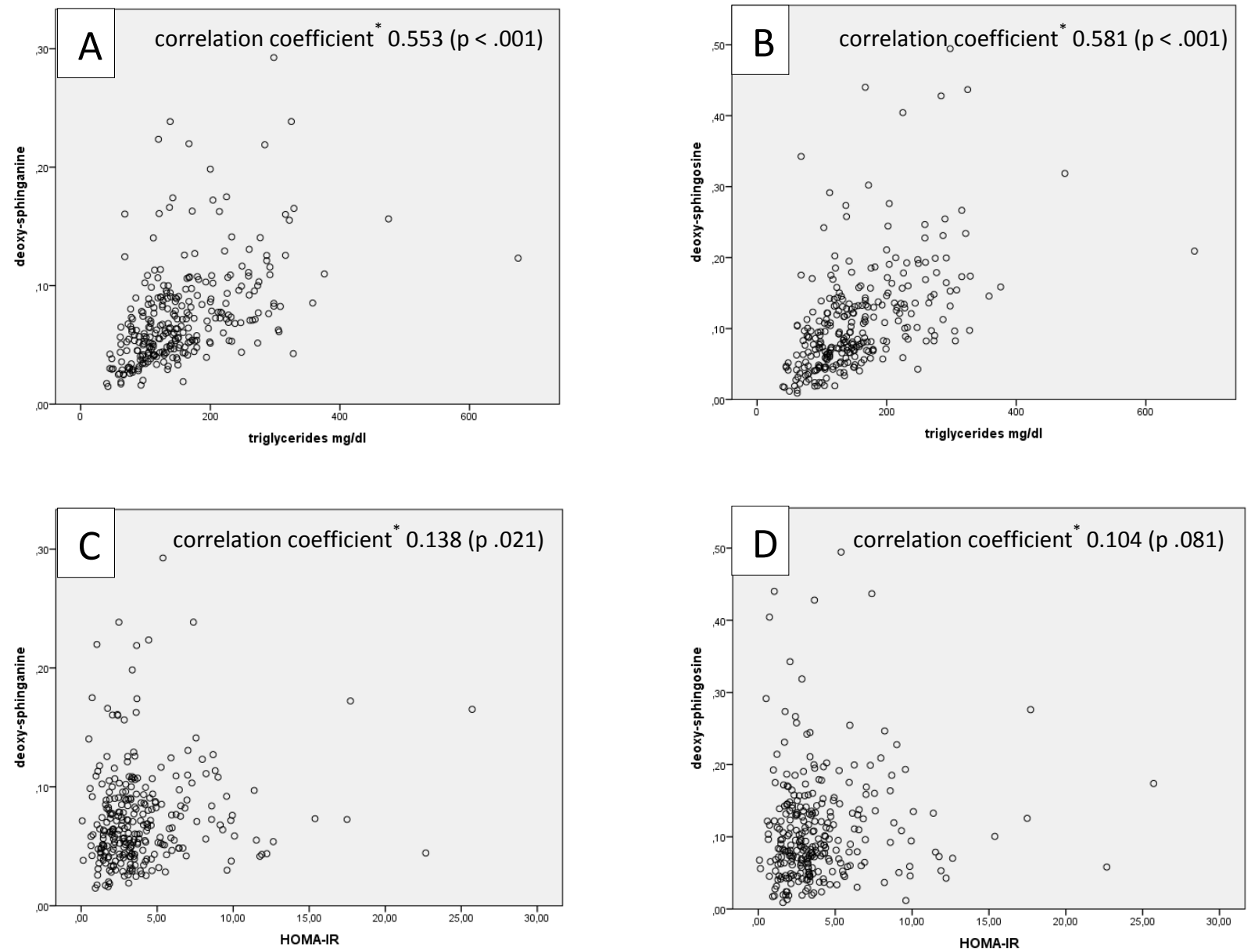

A: Correlation of fasting plasma deoxy-sphinganine and triglyceride levels; $B$ : Correlation of fasting plasma deoxy- sphingosine and triglyceride levels; $C$ : Correlation of fasting plasma deoxysphinganine concentrations and HOMA-IR; $D$ : Correlation of fasting plasma deoxy- sphingosine concentrations and HOMA-IR. * Spearman's rho correlation coefficient and associated $p$-value 